\title{
AVISO
}

Por no disponer de los correspondientes originales informáticos, la maquetación de este artículo difiere de la del publicado en papel. Por lo demás, los contenidos no han sufrido ninguna alteración.

Artículo publicado en el fascículo $2^{\circ}$ del tomo LXV (1997) de EMERITA, pp. 257-279

Autor: Leonard A. Curchin

\section{CELTICIZATION AND ROMANIZATION OF TOPONYMY IN CENTRAL SPAIN}

The toponyms of Central Spain tell us a great deal about the linguistic influence of the Celts and Romans in the interior of the Peninsula. Philological and statistical analysis of the origin of ancient town names in this region reveals a strong predominance of Celtic toponyms among the Celtiberi and Turmogi, while the Arevaci, Pelendones and Vaccaei have equal proportions of Celtic and pre-Celtic names. The highest proportion of Romanized toponyms (about 25 per cent) occurs among the Carpetani and Arevaci.

Toponyms are notoriously resistant to change ${ }^{1}$, and many pre-Roman toponyms in the provinces survived into (and sometimes beyond) the Roman period. The study of provincial toponymy can pay impressive dividends in terms of understanding the acculturation process. On one hand, the number of Latin or Romanized toponyms in a region is a useful index of the impact of the Roman presence, in terms of both the renaming of indigenous settlements and the founding of new ones. On the other, it is instructive to observe that the pre-Roman toponyms of a region rarely belong to a single language, but include remnants of earlier ones as well as borrowings from neighbouring cultures.

One region whose toponymy has not been systematically studied is Central Spain, the territories of the ancient Arevaci, Carpetani, Celtiberi, Pelendones, Turmogi and Vaccaei. Each of these six chiefdoms was either Celtic itself, or strongly influenced by its Celtic neighbours. At the same time, we can also find non-Celtic onomastic elements in all these territories. In this presentation we shall, first, examine the linguistic origin of the individual town-names, and second, analyze the extent to which the toponyms of each chiefdom became successively Celticized and Romanized. While it is not possible in every instance to provide a secure etymology, most toponyms can be classified with some confidence as Celtic, Latin, or neither. Those

1 Cf. L.A. Curchin, Roman Spain. Conquest and Assimilation, London, 1991, p. 188. 
names which are neither Celtic nor Latin may belong to a pre-Celtic IndoEuropean language, or to a para-Celtic language such as Iberian.

Toponymic study has rightly been criticized in the past for its resort to fantastic etymologies and for the prejudice of its practitioners; for instance, Holder listed many names as Celtic that were not, and Pokorny claimed to find «Illyrian» names in unlikely places. Ancient toponyms rarely convey fancy meanings; Celtic place-names, for example, usually describe the site in terms of its appearance or its outstanding feature. Investigators should therefore remember that the simplest meaning is most likely to be the correct one. $^{2}$

Each town listed below is followed by the bracketed abbreviation $\mathrm{A}, \mathrm{Ca}$, $\mathrm{Ce}, \mathrm{P}, \mathrm{T}$, or $\mathrm{V}$, corresponding to the six chiefdoms named above. Other abbreviations include DN (divine name), GN (geographic name), PN (personal name), IE (Indo-European).

Acontia (V). Attested by Strabo (III 3.2) and Stephanus Byzantinus (p. 61M); the latter spells it Acoutia, confusing it with the Aquitani. The toponym appears to be Celtic: the initial element $A c o(n)$ - is found in several Celtic personal and gentilic names (AcS I, pp. 31-32), while the suffix -ntia recurs in GNs such as Segontia.

Alaba (Ce). The spelling Alaba in Ptolemy (II 6.57) is confirmed by the adjectival form Alabensis in inscriptions (CIL II 4200; AE 1987, p. 656); Pliny's Alabanenses (III 25) should therefore be emended to Alabenses. British Alabum and Narbonese Alabon are presumably cognate, possibly from an IE root *alebh-, *alobh- 'hill, crest' (PRB 242), as are the Alabi, a people

\footnotetext{
2 As already pointed out by J.B. Johnston, Place-names of Scotland, 3rd ed., London, 1934, p.21.

3 Also note the following bibliographical abbreviations: $A c S=\mathrm{A}$. Holder, Alt-celtischer Sprachschatz Leipzig, 1896-1907; DAG = J. Whatmough, The Dialects of Ancient Gaul Cambridge, Mass., 1970; ELH = Enciclopedia lingüística hispánica, I, Madrid, 1960; GPN= D.E. Evans, Gaulish Personal Names, Oxford, 1967; Land. = A. Tovar, Iberische Landeskunde, II,3, Baden-Baden, 1989; OPP = M.L. Albertos Firmat, La onomástica personal primitiva de Hispania Tarraconense y Bética, Salamanca, 1966; PRB = A.L.F. Rivet and C. Smith, The Place-names of Roman Britain, London, 1979; TLL = Thesaurus Linguae Latinae; ZCP = Zeitschrift für Celtische Philologie. Epigraphical publications are cited by their usual abbreviations (CIL, Eph. Epig., AE, HAEp); add now HE = Hispania Epigraphica, Madrid, 1989- . IA = Itinerarium Antonini; Rav. = Cosmographia anonymi Ravennatis.
} 
of the Ebro Valley settled at Cortona and named on a Celtiberian tessera. ${ }^{4}$

Albocela (V). Ptolemy (II 6.49) and IA (434.7) both give this spelling, garbled by Rav. (312.20) into Albeceia; the variant Arbocala appears in Polybius (III 14.1, followed by Livy XXI 5.6). The adjectival form Albocolensis found near Salamanca (CIL II 880) may refer to the same place, or possibly to an Albocola in Galicia, as suggested by mention of the metalla Alboc(olensia?) (CIL II 2598, but cf. metallum Albucrarense in Pliny XXX $80)$. The name seems to contain IE *albh- 'white', seen in numerous $\mathrm{PNs}^{5}$ and in the Galician DN Albocelus (CIL II 2394b; cf. DN Alboco[lus?], HE 4, p. 1078), plus a feminine noun *cela 'wood' (cf. Welsh celli, Middle Irish caill, Latin callis), from IE *kel- 'strike, cut'. The name is therefore IE, though not necessarily Celtic.

Albonica (Ce). Mentioned by IA (447.6) as a road station. The name comes from IE *albh- (see preceding entry). The -ica suffix occurs in Celtic GNs in Gaul and Britain (e.g. Robrica, Aesica) as well as in Spain.

Alces (Ca). Mentioned by Livy (XXXX 48, with accusative ending -en) and IA (445.5). Though Livy ascribes this place to the Celtiberians (a term often used loosely to refer to the Spaniards of the interior), the Itinerary distances suggest a location in southeast Toledo or northeast Ciudad Real province, in the territory of the Carpetani. Albertos (OPP, p. 16) assumes a meaning 'deer', citing Greek alke, Latin alces 'elk'. However, these are Germanic loanwords which are unlikely to have penetrated pre-Roman Spain. ${ }^{6}$ Alces therefore remains unexplained, but is in any event non-Latin.

Alternia (Ca). The name occurs only in Ptolemy (II 6.56) and appears to be Latin. An inscription from Orense province, naming Antistius Placidus Cili filius Alterniaicinus (CIL II 2523), seems to provide an adjectival form of the toponym, though of irregular formation; one would expect Alterniensis. Possibly, however, Alternia might be the Latinized spelling of a Celtic

4 For references and discussion, see L.A. Curchin, «Two Alabanenses?», Philologus 139, 1995, pp. 337-338.

5 J. Untermann, Elementos de un atlas antroponímico de la Hispania antigua, Madrid, 1965, maps 4-5.

6 Cf. $D A G$ 1081. The Celtic word for «deer» is * carvo- (cognate with Latin ceruus), seen in the British ethnic name Carvetii and in Old Cornish caruu.

EMERITA. Revista de Lingüística y Filología Clásica (EM) - LXV 2, 1997, pp. 257-279 
toponym: cf. Scottish Altyre (allt tir 'river land') ${ }^{7}$.

Amallobriga (V). The name is spelled Amallobriga in IA (435.1) and on a tessera hospitalis from Montealegre, Valladolid ( $A E$ 1985, p. 581); Rav. (313.2) gives a corrupt form Abulobrica. Although the suffix -briga is of Celtic origin (see below on Augustobriga), the element Amallo- is otherwise unattested; Montenegro suggests that it is pre-Celtic ${ }^{8}$. Cf. however the Old Irish proclitic amal 'like', and the Irish island Amalga ${ }^{9}$.

Ambisna (T). The toponym is thus spelled in Ptolemy (II 6.51); Rav. (318.14) corrupts it to Ambinon. The name comes clearly from Celtic ambi'about' (= Greek amphi-, Latin $a m b-)$; the ending -sna is presumably a contraction of sena, the feminine form of Celtic *seno- 'old' (cf. the British river name Sena: $P R B$ 455). As Evans notes (GPN, p. 134), ambi- may sometimes have an intensive meaning; therefore $\operatorname{Ambis}(e) n a$ should mean 'very old (place)'. On «old» toponyms, cf. Vetera (sc. castra) in Germania Inferior, Oldham in England, and various towns in Spain named Villavieja.

Aquae Bilbilitanorum (Ce). This toponym, attested twice in IA (437.2, 438.14) is clearly Latin, meaning 'the baths of the people of Bilbilis'.

Arcobriga (Ce). The name, given by several sources (Ptol. II 6.57; IA 437.1, 438,13; Rav. 309.17; cf. Arcobrigenses, Pliny III 24), incorporates the widespread ending -briga 'hill-fort'. The initial element is more problematic. Neither Holder's derivation from PN Arquius (AcS I, p. 184) nor Albertos' from *arcto- (OPP, p. 32) is convincing. Schulten thought it was formed from PN Arco, which occurs frequently in the epigraphy of Lusitania and Galicia. ${ }^{10}$ However, Arco also appears, in the dative form Arconi, on two inscribed altars from Riba de Saelices (Guadalajara) in the territory of the Celtiberi. This suggests that Arcobriga is probably a theophoric toponym, 'fortress of Arco', as recently proposed by Francisco Marco. ${ }^{11}$ Another Arco

7 Johnston, Place-names of Scotland, p. 82.

8 A. Montenegro, «La tessera hospitalis del año 134 d.C. hallada en Montealegre», Hispania Antiqua 11-12, 1981-85, p. 113.

9 E. Hogan, Onomasticon Goedelicum locorum et tribuum Hiberniae et Scotiae, Dublin-London, 1910, p. 30.

10 A. Schulten, Numantia, II, Munich, 1914, p. 141.

11 AE 1987, 653 = HE 2 (1990) 425; J. Gómez-Pantoja, «Arco», Actas del II coloquio

EMERITA. Revista de Lingüística y Filología Clásica (EM) - LXV 2, 1997, pp. 257-279 
briga is known in Lusitania (Ptol. II 5.5; CIL II 765).

Arecorada (P). The name occurs as a.r.e.co.ra.ta, and in the adjectival ethnic form a.r.e.co.r.a.ti.co.s, on pre-Roman coins; the ethnic reappears in dative or ablative a.r.e.co.r.a.ti.cu.bo.s on a Celtiberian inscription from Luzaga. If correctly identified with Agreda (Soria) near Augustobriga, it should lie among the Pelendones. Are- is a Celtic prefix equivalent to Latin $a d$ - 'near», while the suffix - $a d a$ is found in others toponyms in our region (e.g. Caesada, Varada). The middle element may come from the Celtic root *kor- 'to place, throw', possibly contained in Gaulish PNs such as Coradus (GPN, pp. 338-39). Arecorada might therefore mean '(the town) placed near' or 'the adjacent (town)', though whether 'near' to a river or to another town is unknown.

Arriaca (Ca). This road station, listed by IA $(436.3 ; 438.19)$ and, in the corrupt form Arentia, by Rav. (310.2), lies slightly nearer to Complutum of the Carpetani than to Caesada of the Celtiberi. The -aca suffix is reminiscent of several indigenous GNs in Central Spain (Autraca, Caraca, Pisoraca) and elsewhere (Belcinaca in Gaul: DAG, p. 597). Since Spain lacks the *ariocompounds found in Gaul, such as PN Arius (GPN, p. 141) and GN Ariolica (DAG, pp. 48, 360), the name probably comes from Latin Arrius, a gentilic name amply attested in the epigraphy of our region.

Attacum (Ce). This is attested by Ptol. (II 6.57) as Attacon; cf. the adjectival form Attacc(ensis) in CIL II 4189. I have argued elsewhere that it is formed from the Celtic PN Atto/Atta plus the toponymic ending -acom. ${ }^{12}$

Augustobriga (P). The town is named by Ptolemy (II 6.53), IA $(442,3)$ and Rav. $(311,2)$ as well as on several milestones. The -briga suffix, a Romanized form of Celtiberian -brik(s) 'hill-fort' (cf. Irish brig 'strength'), is preceded by the Roman imperial name Augustus. Such hybrids are often found, e.g. Caesarobriga and a second Augustobriga in Lusitania; Caesarodunum and Augustodunum in Gaul. Contrary to the old assumption that -bri$g a$ is a remnant of the Hallstatt age, many -briga toponyms are Roman or postclassical. ${ }^{13}$

sobre epigrafia, religiones peninsulares, ed. J. Cardim Ribeiro, Sintra (forthcoming). Cf. F. Marco Simón in Los Celtas en el valle medio del Ebro, Zaragoza, 1989, p. 119.

12 L.A. Curchin, «Five Celtic town-names in Central Spain», Habis 27, 1996, pp. 45-46.

13 The old view is expressed by, e.g., E. Sangmeister, «Die Kelten in Spanien», Madr. EMERITA. Revista de Lingüística y Filología Clásica (EM) - LXV 2, 1997, pp. 257-279 
Autraca (V). Our sole authority is Ptolemy (II 6.49), whose coordinates place it near the confluence of the Odra and Pisuerga. It was recognized more than a century ago that the town must be named after the former river $($ Odra $<*$ Autra); cf. GNs Autura, Autricum in Gaul, and the Autrigones in Spain. ${ }^{14}$ On the -aca ending, see under Arriaca.

Avia (V). Again our only source is Ptolemy (II 6.49). Müller, based on Ptolemy's coordinates, placed it on the modern river Valdavia, perhaps earlier Vallis Aviae? ${ }^{15}$ The IE root *ap- (Celtic, $a b$-, $a v$-) 'flow' occurs in numerous Celtic hydronyms and names of towns located on rivers (cf. PRB 239, 261). A town Avia in northern Spain is mentioned by the monk Grimald in the 11th century, but may be a different site. ${ }^{16}$

Barnacis (Ca). Mentioned only by Ptolemy (II 6.56), it is clearly non-Latin, though of obscure origin. By analogy with Celtic, barn- might mean 'hill' (cf. Old Cornish and Breton bern, Scottish barr, from IE *bhergh-). The suffix -acis, seen in British GNs like Sulloniacis and Vagniacis, could represent Celtic - $a c$ - (cf. Arriaca, Attacum) with Latin locative plural ending -is (PRB 485), but in Spain it tends to occur in para-Celtic contexts (Fornacis in Turdetania, Rodacis in Lusitania). Barnacis may therefore be IE but non-Celtic. Somewhat similar in form is Ptolemy's Bargiacis (II 6.49), which he lists among the Vaccaei - apparently in error, since his coordinates make it coincident with Brigaecium of the Astures.

Belgeda $(\mathrm{Ce})$. The name is so spelled by Appian (Iber., p. 100). Diodorus gives Begeda (XXXI 39), Orosius has Belgida (V 23.11). A mosaic inscription from Segobriga mentions a Belcide[nsis a]rtifex. ${ }^{17}$ The root Belg-occurs sporadically in Celtic nomenclature, e.g. Belgica in Gaul, the town Belgites in Pannonia (Pliny III 148), and the Gallic leader Belgios (Justin 24.5-6; ca-

Mitt. 1, 1960, p. 95. See now M.L. Albertos, «Los topónimos en -briga en Hispania», Veleia 7, 1990, p. 131; S. Piggott in Los Celtas en el valle medio del Ebro, p. 105 (distribution map).

14 H. d'Arbois de Jubainville, «Les Celtes en Espagne», Revue Celtique 15, 1894, p. 33.

15 Claudii Ptolemaei Geographia, ed. K. Müller, Paris 1883, p. 166; cf. E. Hübner, RE II,2, 1896, col. 2372.

16 ee M. Férotin, Histoire de l'abbaye de Silos, Paris 1897, p. 77 note, who thinks it may be Ribadavia.

17 Eph. Epig. VIII, n ${ }^{\circ} 183$ = M. Almagro, Segóbriga II, Madrid 1984, n 42 . The photograph in Almagro disproves the traditional reading Belcile...: the letter preceding the second $\mathrm{E}$ is spaced too far away to be $\mathrm{L}$, and must be $\mathrm{D}$.

EMERITA. Revista de Lingüística y Filología Clásica (EM) - LXV 2, 1997, pp. 257-279 
lled Bolgios by Pausanias X 19.7).

Belsinum (Ce). Ptolemy gives the name as Belsinon (II 6.57), IA variously as Balsione (443.4) and Bellisone (451.1), Rav. as Belsionem (310.18) and Belisarium (313.7). From these sources it is unclear whether the correct form is Belsinum, Belsio, or Beliso. Comparative light is, however, shed by the Aquitanian GN Belsinum, variant Belsino (AcS I, p. 396; $D A G$, p. 246) which is probably homonymous with ours. A possible, though by no means secure, solution is to accept Belsinum and to suppose that its ablative form Belsino misled the copyists of the itineraries into construing it as third declension. The root of the first syllable may be Celtic *bel- 'bright, shining', seen in the Gaulish DN Belenos (identified with the sun-god Apo1lo) and presumably in the Celtiberian GN Contrebia Belaisca. The -sin- ending remains unexplained, though cf. Abusina in Central Europe (DAG, p. 1206).

Bilbilis (Ce). The name, attested in a large number of sources (see $R E$ or $T L L$ ad loc.), is clearly an Iberian formation with reduplicated stem.

Brauum (T). The name is found only in Ptolemy (II 6.51), in the form Brauon. I have suggested elsewhere, using the comparative evidence of British Brauoniacum, that the name is Celtic and may mean 'quern hill' ${ }^{18}$.

Bursao (Ce). Though Ptolemy gives the form Bursada (II 6.57), other sources suggest that the correct spelling is Bursao (Bursaones, Livy fr. 91; «Bursaonenses», Pliny III 24; bu.r.s.a.u, coins). The etymology is probably not Celtic (despite some bur- compounds in Gaulish, $D A G$, pp. 445-46) but Iberian: cf. Burado near Bilbilis (Martial IV 55.23) and Burtina of the Ilergetes (Ptol. II 6.67).

Caesada (Ce). This appears as ca.i.s.e.s.a on pre-Roman coins, but as Kaisada in Ptolemy (II 6.57) and Caesada in IA (436.4; 438.11, cf. Caesaram, Rav. 310.1). The consonant shift from $s$ in the Iberian script to $d$ in classical authors, which is also seen with Sekaisa/Segeda (q.u.), appears to reflect a Celtiberian sound midway between $/ \mathrm{s} /$ and $/ \mathrm{d} /$, such as $/ \mathrm{dh} /$ or $/ \mathrm{z} / .^{19}$ A similar confusion exists in Gaulish (GPN, pp. 414-18), and there is some

18 Curchin, «Five Celtic Town-names», p. 46.

19 See most recently F. Villar, Estudios de celtibérico y de toponimia prerromanas, Salamanca, 1995, pp. 72-73.

EMERITA. Revista de Lingüística y Filología Clásica (EM) - LXV 2, 1997, pp. 257-279 
interchange of $/ \mathrm{s} /$ and $/ \mathrm{d} /$ in the classical languages (Greek $\mu \varepsilon \dot{\sigma o} \varsigma=$ Latin medius; Greek rhodon $=$ Latin rosa, $\mathrm{cf}$. in Cataluña GN Rhode $>$ Roses $)$. The element *caiso- may equate to Gallic gaesum 'javelin' (OPP. 70; DAG, p. 35 ), though the suitability of this meaning to a toponym is not readily apparent. On the -ada ending, cf. Arecorada.

Camala (V). This road station, mentioned only by IA (395.2), is clearly a feminine form of the PN Camalus, widely attested in western Iberia and apparently equivalent to Gaulish Camulus $^{20}$. Its meaning is disputed, though Evans makes it cognate with Irish cam 'fight' (GPN, p. 161).

Caraca (Ca). Ptolemy presents the name as Karakka (II 6.56), Rav. as Caraca (313.10); Plutarch (Sert. 17) refers to its inhabitants as Charakitanoi. The name comprises the element *car-plus the toponymic ending -aca (see Arriaca). As Evans notes (GPN, pp. 162-63) it is difficult to determine whether Car- names come from Celtic caro- 'dear, friend' or carro- 'wagon'; to the latter root may belong a GN Carraca in Cisalpine Gaul (Ptol. III 1.22). However, Evans also cites a pre(?)-IE root karr- 'rock, crag', which would better suit a toponym, especially since Plutarch tells us that the Characitani lived in the side of a cliff.

Cauca (V). The name is so spelled by a large number of sources (see $A c S$ I, pp. 365-366). It is clearly related to such Hispanic PNs as Caucaenus and Corocaucus, which appear to be IE (OPP, p. 83) but pre-Celtic. Cauc- names are infrequent in the Celtic world, e.g. the Cauci in Ireland (Ptol. II 2.9) and Cauca in Narbonensis (CIL XII 5686.208).

Centobriga $(\mathrm{Ce})$. The place is mentioned only by Valerius Maximus (V 1.5). I have proposed elsewhere that the likeliest root is Celtic *cento, *cinto 'first', yielding the meaning 'foremost hill-fort'21.

Certima (Ce). Livy (XXXX 47.2) calls this a town of the Celtiberi. It seems philologically connected to Certis, a river name found in Spain (the Guadalquivir: Livy XXVIII 22.1) and possibly Britain (Rav. 108.33, assuming Certisnassa represents a conflation of two toponyms); also related may

20 Untermann, Atlas antroponímico, p. 85; D.E. Evans, «On the Celticity of some Hispanic Personal Names», II coloquio sobre lenguas y culturas paleohispánicas, Salamanca, 1979, p. 122.

${ }^{21}$ Curchin, «Five Celtic Town-names», p. 46. 
be Certisa in Pannonia (Ptol. II 15.4; IA 260.9) and Certhaine in Ireland ${ }^{22}$. Several scholars have traced the river name to Celtic *qert- 'to turn, twist' (see PRB 307), and this might also be the root of Certima, perhaps describing a site located at a river bend.

Clunia (A). Numerous literary and epigraphic sources agree on the spelling of this name, but its etymology is obscure: «vielleicht iberisch» according to Holder (AcS I, p. 1048), «keltisch oder ligurisch» according to Schul$\operatorname{ten}^{23}$. Carnoy evoked a root *klu- 'clean water'. citing such unlikely parallels as Clyde in Scotland and the river Lauer $<*(k) l u$-ro. Montenegro, pointing to Clunian coins depicting a boar, claims a root ${ }^{*}$ clun- 'boar» for which he

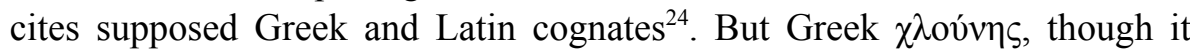
came to signify 'wild boar', was originally an adjective, variously interpreted as 'castrated', 'solitary', 'foaming' or 'crouching', and Latin clunis 'ham' is not a porcine reference but means 'buttock' and is cognate with Breton klun, Welsh clun 'thigh'. In any event, the boar is well known as a sacred animal among the Celts, and its appearance on Clunia's coinage need not imply an etymological connection. Tovar (Land., p. 352) proposes a derivation from IE *kel- ('to rise'), but this does not account for the vocalism of Clu-. A Celtic root *clu- is suggested by Welsh clyw, Irish clú 'fame, glory', but this would not explain the $n$ in our toponym. The name may therefore be pre-Celtic, paralleled by Clunia in Raetia (Tab. Peut. 3.5) and Cluny $<{ }^{*} C l u$ niacum in Savoy ${ }^{25}$.

Colenda (A). With this toponym, mentioned by Appian (Iber. 99-100), may be compared the Latin cognomen Colendus ${ }^{26}$. The gerundive of the verb colo-ere, it may designate a town founded or renamed by the Romans prior to 93 B.C. Alternatively, Appian's Kolenda might be a garbled form of a cal-toponym, or even of Clunia. Another possibility is to relate it to Irish coll 'hazel', Scottish coille 'wood' (cf. above on Albocela), but this does not

22 Hogan, Onomasticon goedelicum, p. 230.

23 Schulten, Numantia, I, p. 131.

24 A.J. Carnoy, Dictionnaire étymologique du Proto-indo-européen, Louvain 1955, p. 119; A. Montenegro in Historia de Burgos, I. Edad antigua, Burgos 1985, p. 246.

25 J. Pokorny, «Zur Urgeschichte der Kelten und Illyrier», ZCP 21, 1938, p. 153, who makes Clunia an Illyrian name.

26 I. Kajanto, The Latin Cognomina, Helsinki 1965, p. 360.

EMERITA. Revista de Lingüística y Filología Clásica (EM) - LXV 2, 1997, pp. 257-279 
explain the ending.

Complutum (Ca). The name is spelled co.n.bo.u.to on pre-Roman coins (using the Iberian script which lacks the letter «p»), Konplouton in Ptolemy (II 6.56), and Complutum in a wide range of Latin sources (see TLL ad loc.). The un-Celtic combination $p l$ has generated much etymological speculation. Flórez thought the name was Greek, from kôme + ploutos ${ }^{27}$; Holder considered it «wahrscheinlich iberisch» (AcS I, p. 1087); others have classed it as IE but pre-Celtic, derived from *pleu- 'to flow' and thus meaning 'confluen$\mathrm{ce}^{28}$. Although Corominas and Hamp have suggested that Complutum might be Celtic after all ${ }^{29}$, the matter remains in doubt. An undoubtedly related Complutica is attested in Galicia (Ptol. 2.6.38).

Confluenta (A). Ptolemy lists this in the Hellenized form Komphloenta (II 6.55). It is clearly Latin, from the verb confluo, and indicates a town situated at a river junction. Several places of the same name are known in other Roman provinces (see TLL, Suppl II, 562).

Consabura (Ce). Ptolemy (II 6.57) lists Kondabora among the Celtiberi, but its traditional location at Consuegra (Toledo) places it among the Carpetani. Pliny (III 25) and several inscriptions give the name of the inhabitants as Consaburenses. Frontinus (strat. IV 5.19) provides a contracted form Consabra, while the itineraries alter its gender to Consabro (IA 446.6) or Consabron (Rav. 313.15). Ptolemy's $-d$ - may be either a manuscript error, or the confusion of $s$ and $d$ in Celtiberian (see above on Caesada). A tessera from Herrera del Pisuerga (HAEp 2452) mentions the Cusaburenses, apparently a homonymous people of the north. The name comprises the Celtic or Latin prefix co(n)- plus an unidentified verbal root sabur-. Cf. below on $\mathrm{Sa}$ baris.

Contrebia Carbica $(\mathrm{Ca})$. The name appears on coins as ca.r.bi.ca (variant

27 E. Flórez, España sagrada, VII, Madrid 1751, p. 161.

28 Hubschmid, ELH, p. 484; A. Tovar in Geschichte und Kultur der Kelten, ed. K.H. Schmidt, Heidelberg, 1986, p. 90. G. Alföldy, Römisches Städtewesen auf der neukastilischen Hochebene, Heidelberg 1987, p. 101 implausibly takes Complutum as a Latin translation of the pre-Roman GN Complega.

29 J. Corominas, «New Information on Hispano-Celtic from the Spanish Etymological Dictionary», ZCP 25, 1956, p. 38; E.P. Hamp, «Hispanic Complutum, Compleutica», ZCP 39, 1982, p. 204.

EMERITA. Revista de Lingüística y Filología Clásica (EM) - LXV 2, 1997, pp. 257-279 
ca.r.bi.co.m) co.n.te.ba.co.m. Livy (XL 33) refers to a Contrebia among the Carpetani, which (since it cannot be Contrebia Leukade or Contrebia Belaisca) is presumably Carbica. Possibly Carbica is the Celtic form of the Latin adjective Carpetana: a similar confusion can be seen in a town of Narbonensis which the sources variously spell Carbantorate or Carpentorate (DAG, $\mathrm{p}$. 178). A stone from Guadalajara province, inscribed ca.r.bi.s.ca, could mark the territorial boundary of the Carpetani, though this is a subject of controversy $^{30}$. For the -ica suffix, cf. below on Sentica. Contrebia is Celtic, formed from *con- 'together' plus *treb- 'dwelling' (Irish treb, Welsh athref ); cf. the Arotrebae in Galicia, Atrebates in Belgica, and the British GN Locatre$b e$. A deity Contrebis is mentioned in two inscriptions from Britain ${ }^{31}$.

Contrebia Leucada (P). Livy (fr. 91) refers to Contrebia quae Leucada appellatur as a Roman grain depot among the Arevacos et Cerindones (= Pelendones, by confusion of Celtic $q$ - and $p$-) and on the escape route from the land of the hostile Berones. ${ }^{32}$ Since the Berones border on the Pelendones, Leucada should belong to the latter. On the name Contrebia, see the preceding entry. Leucada contains Celtic *leuc- 'shining, white' (cognate with Greek leuk- 'white', Latin lucere 'to shine'), perhaps referring to the white rock outcrop which forms the presumed site of this town, near Inestrillas in Logroño. Cf. Leuciana, a station on the road from Mérida to Toledo (IA 438.5). On the ending -ada, cf. Arecorada.

Cougion (V). Both Ptolemy (II 6.49) and Rav. (313.6) give the spelling Cougion, which appears to be the neuter of the indigenous PN Cougios, attested at Termes in the genitive form Cougio (Eph. Epig. VIII, 148). Its etymology is unknown.

Deobrigula (T). Attested by Ptolemy (II 6.51) and IA (449.6; 454.3), this is a diminutive of Deobriga (Celtic *devo-briga) 'the god's hill-fort'.

30 J. Untermann, «Comentarios sobre inscripciones celtibéricas 'menores'», Studia Indogermanica et Paleohispanica in honorem A. Tovar et L. Michelena, ed. F. Villar, Salamanca, 1990, pp. 353-354.

31 R.G. Collingwood and R.P. Wright, The Roman Inscriptions of Britain, I, Oxford, 1965, núms. 600,610 .

32 There is no reason to suppose, as scholars often have, that Leucada was a town of the Berones - it would make no sense for Rome to entrust her grain to an enemy town - nor (from the initial element $\mathrm{Leu}$-) that it belonged to the Lusones.

EMERITA. Revista de Lingüística y Filología Clásica (EM) - LXV 2, 1997, pp. 257-279 
Dessobriga (T). This road station is known only from IA (449.4). Though Montenegro argues that the double $s$ makes the name non- $\mathrm{IE}^{33}$, Holder (AcS I, p. 1272) points to the Celtic root *desso- $(<*$ dexso-; cf. Old Irish dess $)$ 'right', cognate with Greek dexios, Latin dexter. The name might denote a town on the right bank of a river.

Egelasta. Ptolemy alone (II 6.56) locates this town among the Carpetani; it should rather be among the Bastetani (Strabo III 4.9; Pliny III 25, cf. XXXI 80).

\section{Eldana: see Saldania}

Ercauica $(\mathrm{Ce})$. The name appears on pre-Roman coins as e.r.ca.u.i.ca. It is rendered Ergauica by Livy (XXI 50.1) and Ergaouika by Ptolemy (II 6.57). Pliny (III 24) refers to the Ercauicenses; cf. dative Ercavic(ensi) (CIL II 4203). The name is Celtiberian, according to Holder ( $A c S$ I, p. 1458); Tovar, citing the authority of G. Bähr, gives the meaning «bunte Siedlung» ${ }^{34}$. This interpretation presumes that -vica is a feminine cognate of Greek oîko , Latin uicus, but the likelihood of such a gender change has already been challenged ( $P R B$ 332). The alternative recourse is to IE *weik- 'fight, conquer', whence Latin uinco, uictum (GPN, pp. 281-83); the Romans indeed had a goddess Vica Pota 'victress-protector'. This root presumably underlies the numerous Gaulish local and ethnic names in -vices, as well as the British GNs Delgovicia, Longovicium and Vercovicium. With the first element, cf. $E r c$, a king of Dál Riata in northern Ireland mentioned in the Annals of Tigernach. Erca in our example could be a DN: a deity Erga is attested in Gaul (DAG, p. 254). Evans (GPN, p. 284) cites an Insular Celtic PN Ercavicca which surely contains the same elements. There is another Ergauica among the Vascones (Pliny III 24; Ptol. II 6.66), and an inscription from León mentions Ergauici ${ }^{35}$.

Gela or Tela (V). Ptolemy gives the form Gella (II 6.49), Rav. Gela (318.17), IA Tela (440.3, perhaps misreading the gamma in a Greek source). The name might be Celtic, cf. Gelovium in Britain (possibly from *gel'leech': PRB 367), Gelduba in Germany, and Gelidaua in eastern Europe

33 A. Montenegro in Historia de Palencia, I, ed. J. González, Palencia, 1984, p. 55.

34 A. Tovar, «Léxico de las inscripciones ibéricas (celtibérico e ibérico)», Estudios $\mathrm{Me}$ néndez Pidal, II, Madrid 1951, p. 281.

35 F. Diego Santos, Inscripciones romanas de la provincia de León, León, 1986, nº 183.

EMERITA. Revista de Lingüística y Filología Clásica (EM) - LXV 2, 1997, pp. 257-279 
(DAG, pp. 925, 1217); cf. also the suffix -cela in Albocela, above. Holder claims Celtic GNs *Gelli and *Gelle as the roots of modern French Jaux, Gilles (AcS I, p. 1994). If Tela is the correct name, cf. GNs Telo, Telonnum in Gaul $(D A G$, pp. 186, 611) and perhaps Old Irish telach 'hill'.

Histonium (Ce). Ptolemy's form Istonion (II 6.57) has apparently lost its aspiration; an inscription from Cáceres province mentions a Histiniensis (HAEp 212). The etymology is uncertain: Tovar (Land., p. 221) points to another Histonium on the Adriatic, while Pokorny invokes as «Illyrian» parallels Istonion in Samnium and Istone on Corcyra ${ }^{36}$.

Ilarcuris (Ca). Mentioned only by Ptolemy (II 6.56), its first element has numerous parallels in Iberian, where ilu-, ili- means 'city' (Ilurco, Iluro, Iliberris, etc.). The suffix is paralleled in the GN Gracchuris.

Ilurbida (Ca). Again Ptolemy (II 6.56) is our only source, and again the initial element is Iberian. Comparable names include the Iluberitani of the Ebro valley (Pliny III 24) and Idubeda, a mountain of Celtiberia (Strabo III 4.12).

Intercatia $(\mathrm{V})$. This town is mentioned in numerous literary sources (Livy, Epit. 48; Strabo III 4.13; Val. Max. III 2.6; Pliny, III 26; Ptol. II 6.49; App. Iber. 53-54) and inscriptions (CIL II 2786, 4233, 5763, 6093). Another Intercatia is attested as castellum in Asturias (Ptol. II 6.31; CIL XIII 8098). Inter- has variously been seen as a Celtic or Latin element ${ }^{37}$; its cognates include Irish eter, Breton entre, Cornish ynter (AcS II, p. 56). However, since Intercatia is first mentioned as a Vaccaean town besieged by the Romans in $151 \mathrm{BC}$, its name can hardly be Latin. The ending -catia recalls Gaulish PNs Catius / Catia, ethnic names Abrincatui, Caeracates and Volocates, and the gloss «cateia: telum Gallicum» (GPN, pp. 171-75), probably all from *catu- 'battle'. The name perhaps means '(town) in the midst of battle'.

Ispinum (Ca). The form attested in Ptolemy (II 6.56) may - like Eldana and Istonium - have suffered loss of aspiration. It could therefore be Iberian, from the same root as Hispalis.

36 Pokorny, «Urgeschichte», p. 153.

37 F. Wattenberg, La región vaccea, Madrid, 1959, p. 66 (Celtic); L. Calvo Lozano, Historia de Villalpando, Zamora, 1981, p. 21 (Latin); Montenegro, Historia de Palencia, I, pp. 55-56 (Latinization of indigenous element).

EMERITA. Revista de Lingüística y Filología Clásica (EM) - LXV 2, 1997, pp. 257-279 
Lacobriga (V). The town is mentioned by Pliny (III 26), Ptolemy (II 6.49 ) and the IA $(395.1 ; 449.3 ; 454.1)$; also in lexical glosses, in the forms Laccobriga and Lactobriga ${ }^{38}$. In Lusitania, a Laccobriga is attested by Ptolemy (II 5.5), and Langobriga by Plutarch (Sert. 13) and the itineraries (IA 421.7; Rav. 307.3). The GN Laccoburgo or Laciburgion is recorded in Central Europe ( $D A G$, p. 1219). A gloss derives the first element of Lacobriga from Latin lacus, but this sounds like folk etymology. Possibly Lac(c)obriga is for Lactobriga, from *lacto- 'milk' like Lactodurum in Britain (PRB 382) and perhaps Lactora in Aquitania (DAG, p. 248); but this too seems fanciful and gives poor semantic sense. Alternatively, Laco- might designate a PN or DN for whom the town was named, though no such name is attested. If Lac(c)- and Lang- represent Lag-, the name might be related to GNs Lagina, Lagania and Lagecio (or Lagentium?: PRB 383); cf. Sanskrit laghu, Greek elachys 'small', cognate with Old Irish laigiu; also Scottish and Irish lag 'hollow, cave'. On balance, Laco- seems most likely to be IE but non-Celtic. On -briga, see Augustobriga.

Laminium (Ca). The name appears as Laminion in Ptolemy (II 6.56), as ablative Laminio in IA (446.8; cf. Rav. 313.17), and in the adjective Laminitanus (Pliny III 1.6; CIL II 3228, 3251-52). Though Fita ineptly connected it with Greek $\lambda \mu \eta v^{\prime}$ 'harbour ${ }^{\prime 39}$, it is probably related to the indigenous PN Laminus, attested in Toledo province (CIL II 934). Evans cites possible parallels Lamia, Lamenus, Lamis, etc. (GPN, p. 456), perhaps cognate with Old Irish lam 'hand'. However, a non-Celtic origin is equally likely. A GN Lama is recorded among the Vettones (Ptol. II 5.7).

Laxta (Ce). This name is known from Ptolemy (II 6.57), an inscription of two Laxt[e?]nses at Segobriga (CIL II 6338ff), and a possible Laxste[nsis] at Vildes (Jaén) ${ }^{40}$. Holder assumes a feminine name from root *lax- (AcS II, p. 166), which he does not explain (perhaps IE *laks- 'salmon', referring to the local catch).

38 W. M. Lindsay, Glossaria Latina, IV, Paris, 1930, p. 243.

39 F. Fita, «Excursión arqueológica por Villar del Rey, Alhambra ... y Orense», BRAH 42,1903 , p. 283 and note 2.

40 C. González Román and J. Mangas Manjarrés, Corpus de inscripciones latinas de Andalucia, III: Jaén, Sevilla, 1991, n 57 , revising the reading of F. Fita, BRAH 61, 1912, p. 520 .

EMERITA. Revista de Lingüística y Filología Clásica (EM) - LXV 2, 1997, pp. 257-279 
Libana (Ce). The name appears only in Ptolemy (II 6.57). Its etymology is unknown. Other lib- toponyms, not necessarily all Celtic, include Libarna in Liguria, Libica in Gaul, Libia of the Berones, and Libora of the Carpetani. A duplicate of Libora (below) is not to be excluded.

Libora (Ca). This spelling is given by Ptol. (II 6.56); Rav. has Lebura (312.11). Livy's Aebura (XL 30-33) could have resulted from a misreading of the name in Polybius (confusion of alpha and labda), though Tovar rejects its identity with Libora (Land., p. 235). The name might be Celtic: Holder cites a Gaulish PN Liborius (AcS II, p. 205).

Lutia (Ce). Lutia, mentioned by Appian (Iber., p. 94), appears in the adjectival form l.u.ti.a.co.s on pre-Roman coins, and l.u.ti.a.ce.i on the bronze tablet from Luzaga; Luzaga itself is presumably descended from (civitas) Lutiaca. Arbois de Jubainville assigned it to the same stem as Lutetia in $\mathrm{Gaul}^{41}$, which comes, however, from Lucotecia (DAG, p. 605). A likelier root may be Celtic *luta 'mud, marsh', cognate with Latin lutum (PRB 403).

Mantua (Ca). The name is given by Ptolemy (II 6.56). It is homonymous with Mantua in Cisalpine Gaul; a PN Mantua is also known (CIL II 5321). A possible root is Celtic *mandu- 'small horse, pony' (PRB 411).

Mediolum (Ce). Only Ptolemy (II 6.57) names this town. The Celtic root *medhio- meaning 'middle' (like Latin medius) is seen in such toponyms as Mediolanum in Cisalpine Gaul, Medionemeton in Britain, and possibly Medioga in Galicia (Rav. 308.4).

Meoriga (V). The town is named by Sallust (hist. II 92), and in some manuscripts of Ptolemy (II 6.49) in place of Lacobriga. The element meo- is unexplained; the ending may represent Celtic *rig- 'king', cognate with Latin rex. Alternatively, the name could be a corrupt form of *Mediobriga 'on the middle of the hill'.

Metercosa (Ca). Our sole authority is Ptolemy (II 6.56). Its etymology is unclear: Hübner makes it Iberian, while Holder cites possibly Celtic PNs Meteriola and Meterius (AcS II, p. 578).

Miacum $(\mathrm{Ca})$. The name is known only from IA (435.6). There is no known Celtic stem *mio-, though the fragmentary British toponym Mio[.]edum(?) (PRB 418) might be related. The zero-grade form *mi- of IE

41 Arbois de Jubainville, «Les Celtes en Espagne», p. 22. 
*mei- 'small' is a conceivable root. The suffix -acum is found in numerous Gaulish toponyms, though Holder (AcS II, p. 581) thought the name might be Iberian.

Murum (Ca). IA gives Murum (446.5), Rav. Moroin (313.16). Schulten suggests that the name is a Latin accusative, «(ad) Murum» ${ }^{42}$, perhaps rightly.

Nertobriga (Ce). The name appears in literary sources (App. Iber. 48; Florus I 33; Ptol. II 6.57), itineraries (IA 437.4, 439.2; Rav. 309.15) and coins (n.e.r.to.bi.s, sc. Nertobi(rice)s). Another Nertobriga is known in Baetica (Ptol. 2.4.10; Eph. Epig. VIII, 82). The name is Celtic for 'strong fortress', cf. Gaulish nerto- 'strength' (GPN, p. 237), Irish nert, Welsh nerth.

Nivaria (V). This is named in IA (435.4); Rav. (313.1) gives Nibaria. Holder lists several «Celtic» GNs and PNs in niv-, though some may be loan words from Latin (like Breton niver, Cornish nyver 'number', derived from numerus) $;{ }^{43}$ also cf. Novaria in Cisalpine Gaul.

Noua Augusta (A). Attested by Pliny (III 27), Ptolemy (II 6.55) and an inscription ( $A E$ 1972, p. 282), the name is clearly Latin. On Augustan toponyms, see above on Augustobriga. On «nouus» names, cf. Oppidum Nouum in Aquitania.

Numantia (P). Though mentioned by a long list of sources, this toponym is difficult to explain. The -nt- suffix is $« \mathrm{P} »-$ Celtic (PRB 456; Land., p. 361 ), but Numa-remains a puzzle. Hubschmidt derived it from the same preRoman root as Numana in Picenum ${ }^{44}$, though the connection is tenuous. Possibly related is the brickmaker's name Numacianus, attested in Zamora province $^{45}$.

Ocelodurum (V). I have argued elsewhere that this toponym (attested in Ptol. II 6.49 and in the itineraries) is Celtic, from *ocelo- 'promontory' plus

42 A. Schulten, «Murum», RE XVI,1, 1933, col. 679.

43 H. Lewis and H. Pedersen, A Concise Comparative Celtic Grammar, 3rd ed., Göttingen, 1974, p. 63.

44 Hubschmidt, ELH 471. In the same vein, cf. A. Schulten, Numantia, II, Munich, 1931, p. 84.

45 O(fficina) Numacian(i): R. Martín Valls and G. Delibes de Castro, «Hallazgos arqueológicos en la provincia de Zamora (VI)», BSEAA 45, 1979, p. 145.

EMERITA. Revista de Lingüística y Filología Clásica (EM) - LXV 2, 1997, pp. 257-279 
*duro- `fort ${ }^{46}$.

Ocilis (Ce). Recorded only by Appian (Iber., pp. 47-48), this name probably contains the stem *ocelo- 'spur' seen in Ocelodurum (above), the Alpine GN Ocelo (DAG, p. 45), and Ocelum, a toponym found in Britain and Spain (Ptol. II 3.4; II 5.7; II 6.22). The name may have been Ocelis, as suggested by its presumed modern site, Medinaceli $<$ Arabic medina $+{ }^{*}$ Oceli (Land., p. 407).

Palantia (A). Palantia of the Arevaci (modern Palenzuela) is homonymous with Palantia of the Vaccaei (modern Palencia): see next entry.

Palantia (V). The name is attested in a wide range of literary and epigraphic sources (AcS II, pp. 923-25), usually with a single $l$; the $l l$ spelling in some Greek writers may be due to confusion with the Greek goddess Pallas and the Arcadian GN Pallantion. Attempts have been made (none decisively) to trace the name to IE *pel- 'to flow', *pal- 'marsh', or *pa- 'to defend ${ }^{\prime 47}$; the -ntia ending confirms that the name is IE (see above, Numantia). Possibly related are Palanticus (DN?) and the Palantenses, both in Lusitania $^{48}$.

Paterniana (Ca). The name, mentioned only by Ptolemy (II 6.56) is definitely a Latin formation, though perhaps translating an indigenous concept; the names Paternus and Maternus are especially common in Celtic lands.

Pintia (V). Ptolemy (II 6.49) and IA (440.4) record this toponym. The element pint- is a variant of pent-, both of which are found in PNs in Lusitania and western Tarraconensis (OPP, pp. 180-83). Though from the IE root *penkwto- 'fifth', and cognate with Latin Quin(c)tius, Pintia does not seem to be Celtic ${ }^{49}$. Another Pintia is known among the Lucenses of Galicia (Ptol.

46 Curchin, «Five Celtic Town-names», pp. 46-47.

47 Hubschmid, ELH 485; U. Schmoll, Die Sprachen der vorkeltischen Indogermanen Hispaniens und das Keltiberische, Wiesbaden 1959, p. 72; H. Krahe, Unsere ältesten Flussnamen, Wiesbaden 1964, p. 49; J. Untermann, «Lusitanisch, keltiberisch, keltisch», Veleia 23, 1985-86, p. 64.

48 R. Hurtado de San Antonio, Corpus provincial de inscripciones latinas (Cáceres), Cáceres, 1977, n 773, cf. J.M. Blázquez, Diccionario de las religiones prerromanas de Hispania, Madrid, 1975, p. 137; HAEp 1417.

49 F. Villar, «Los antropónimos en Pent-, Pint- y las lenguas indoeuropeas prerromanas de la Península Ibérica», Indogermanica et Caucasica. Festschrift für K.H. Schmidt, ed. R. 
II 6.22).

Pisoraca (T). Sisaraka according to Ptolemy (II 6.51); Pistoraca, variant Pisoraca in Rav. (318.13); Pisoraca on milestones (CIL II 4883-84, 4888). Though Pokorny tried to make the name Illyrian, comparing Pisaurum in Umbria $^{50}$, the toponymic suffix -aca appears Celtic (see above, Arriaca). Cf. the Pisauae in Narbonensis ( $D A G$, p. 184).

Porta Augusta (V). Mentioned only by Ptolemy (II 6.47), this GN is patently Roman.

Rauda (V). Ptolemy (II 6.49) and IA (440.5) agree on this spelling. Holder (AcS II, p. 1083) connects it to the IE adjective *reudh-, *roudh- 'red' (seen in Irish rúad, Lithuanian raudas, Latin rufus). Onomastic parallels include the PN Rauda (CIL VI, 3345b), the Campi Raudii in Piedmont (Vell. Pat. II 12.5; Florus I 38.14), Roudium in Belgica (DAG, p. 772), and the Vicus Roudensis in Lusitania ${ }^{51}$; possibly also Rodacis in Lusitania (Rav. 312.15) and Rodomagus in Narbonensis (DAG, p. 609).

Rigusa (Ca). Our only witness is Ptolemy (II 6.56). Although the name might come from Celtic *rig- 'king' (cf. Rigomagus in Gaul, Rigodunum in Britain), the -usa suffix lacks Celtic parallels. Another possibility is the preIE root *ric-, *reg- 'height', found in various European names (PRB 514) including perhaps the Celtiberian GN Rigae (Martial IV 55.19) and the Riguscae of southern Raetia (Ptol. II 12.2; Rugusci in Pliny III 137). Possibly usa is a mutation of Iberian -osa, cf. Lezuza $<$ Libisosa, Toulouse $<$ Tolosa.

Sabaris or Sabaria (V). Spellings include Sarabis (Ptol. II 6.49, with transposed consonants), Sebarium (Rav. 319.6), Sabaria (Isid., Hist. Goth. 49; Johan. Biclar., Chron. 27); the manuscripts of IA (434.5) variously give Sabaris, Sabaria, Sibarim, Sibariam (cf. AcS II, p. 1364). Its etymology is unclear, but perhaps related to a pre(?)-IE hydronymic root *sab-. Other possible sab(a)r-compounds include Sabaria or Savaria in Pannonia, the river Sabrina (Severn) in Britain, French Sèvres < *Savara, and Irish Sabrann < *Sabrona (cf. PRB 450-51). Another option is to view Sabaria as *Samba-

Bielmeier and R. Stempel, Berlin-New York 1994, pp. 234-64.

50 Pokorny, «Urgeschichte», p. 51.

51 L.A. Curchin, «Vici and pagi in Roman Spain», Revue des Études Anciennes 87, 1995 , p. 330.

EMERITA. Revista de Lingüística y Filología Clásica (EM) - LXV 2, 1997, pp. 257-279 
ria, comparing the river Sambra in Belgica ( $D A G$, p. 773).

Saldania (V). Elsewhere I have argued that Ptolemy's Eldana (for Helda$n a$ : II 6.49) is to be identified with the Saldania mentioned on Roman inscriptions and Visigothic coins. ${ }^{52}$ A similar confusion of spelling occurs with Helmantica-Salmantica. The name appears to be non-Celtic; cf. Saldis in Central Europe (DAG, p. 1228).

Savia (P). The name, cited only in Ptolemy (II 6.53), is of uncertain origin. With it may be compared Savia in Sarmatia (Peripl. Pont. Eux. 8), the river Sabis in northern Gaul, and the Diocletianic province Sabia in Upper Pannonia. Late sources suggest the existence of a GN Saviae near Paris ${ }^{53}$. If Celtic, the name might be connected with Welsh sefyll 'to stand', Breton sevel 'to erect'; but a non-Celtic origin seems likelier.

Segeda or Segida (Ce). Both spellings are amply attested in literary sources (see $A c S$ II, p. 1437-38). The town's pre-Roman coinage bears the legend s.e.ca.i.s.a, the second $s$ apparently representing $d s$ or $z$ (see above, Caesa$d a$ ). The name is Celtic, from *sego- 'strength, victory'. For the form Sege-, cf. British Segedunum and Segelocum. For Segi-, cf. Segida Restituta in Baetica. For Secais-, cf. the 'well of Segais' in Irish legend ${ }^{54}$.

Segisama Iulia (V). Though Pliny (III 26) ascribes this town to the Turmogi, the combined evidence of Polybius (XXXIV 9.13) and Ptolemy (II 6.49) places it among the Vaccaei; Pliny may have been misled by the similarity of this name to Segisamo. As with Segisamo (see next entry), the name is a Celtic superlative; the feminine form can be seen in the Gaulish DN Belisama and the Spanish mint l.e.ta.i.s.a.m.a. Since Florus (II 33.48) mentions that Augustus came to Segisama and set up his camp there, it was obviously a pre-Roman town that subsequently received an imperial surname, rather than a new Roman foundation. Segisama Iulia is to be distinguished from Segisama Brasaca (CIL II, 4157), of unknown location.

Segisamo (T). It is clear from Pliny («Segisamonenses et Segisamaiulienses»: III 26) that Segisamo is distinct from Segisama Iulia. Ptolemy, moreo-

52 L.A. Curchin, «Ptolemy and the Lost City of Eldana», Hermes 124, 1996, pp. 123128.

53 C. Jullian, «Chronique gallo-romaine», Revue des Études Anciennes 24, 1922, p. 261.

54 N. Chadwick, The Celts, Harmondsworth, 1970, p. 173.

EMERITA. Revista de Lingüística y Filología Clásica (EM) - LXV 2, 1997, pp. 257-279 
ver, assigns Segisamon (variant Setisakon) to the Turmogi (II 6.51) but Segisama to the Vaccaei (q.v.). The name appears as s.e.k.i.s.a.n.o.s on coins, Segesamone in IA (449.5, cf. 454.2), Segisamone in Rav. (318.12), and Segisamo in epigraphy (CIL II 5741, cf. 2915). The name is a superlative of Celtic *sego- 'strong'; for the -samo- suffix, cf. the divine epithet Rigisamus. The PN Segisamus occurs on an inscription (CIL II 5713).

Segobriga $(\mathrm{Ce})$. The name is given in numerous literary and epigraphic sources (cf. AcS II, pp. 1445-46) and is composed of Celtic *sego- (see Sege$d a$ ) and -briga 'hill-fort'. Cf. the Segobrigii of Gaul, in whose territory the Phocaeans founded Massilia ( $D A G$, p. 185).

Segontia (A). The name is attested in a large number of literary and epigraphic sources (see $A c S$ II, p. 1448); its Arevacan affiliation is assured by Pliny (III 27). Whether this is the same as Segontia Lanka, also of the Arevaci (Ptol. 2.6.55; cf. coins of l.a.ka.s), is uncertain; Gómez-Pantoja claims to identify nine different Segontias in Spain ${ }^{55}$. The name comes from Celtic *sego- (see above, Segeda) plus the Celtic toponymic ending -ntia. Onomastic parallels include the PN Segontius in Gaul and Spain, the British chiefdom Segontiaci, and the British GN Segontium.

Segontia Paramica (V). This town is named only by Ptolemy (II 6.49), who confusingly locates another(?) Segontia Paramica among the Varduli (II 6.65). On the name Segontia, see preceding entry. Paramica is an adjective, presumably related to Spanish páramo 'lofty plain', describing the location of the site.

Segovia (A). This name is provided in numerous sources (see $A c S$ II, pp. 1452-53). Pliny (III 27) and Ptolemy (II 6.55) agree that it belonged to the Arevaci. Livy's statement (fr. 91) that the Romans raised infantry among the Arevaci, and cavalry at Segovia and among the Vaccaei, need not mean (as some have assumed) that Segovia was Vaccaean; indeed, the Arevacan town of Colenda, if scholars correctly locate it at modern Cuéllar, effectively severs Segovia from the Vaccaei. The name comes from *sego- (cf. above, Segeda), plus the Celtic toponymic ending -ovia, seen in Gergovia ${ }^{56}$. A

55 J. Gómez-Pantoja, «Notas históricas sobre la zona del Alto Henares en época romana», La celtización del Tajo superior, ed. J. Valiente Malle, Alcalá de Henares, 1992, pp. 118-119. Pliny (III 27) rightly notes that the name Segontia is common in other regions.

56 J. Corominas, «Suggestions on the Origins of some old Place Names in Castilian EMERITA. Revista de Lingüística y Filología Clásica (EM) - LXV 2, 1997, pp. 257-279 
ciuitas Segouiorum is recorded in the Cottian Alps (CIL V 7231), and there is another Segovia in Baetica (Caes., Bell. Alex. 57).

Sentica (V). The name is attested, in the form Sentice, in Ptolemy (II 6.49), IA (434.3) and Rav. (319.8). I have suggested elsewhere that the nominative is Sentica and that it comes from Celtic *sento- 'path' plus the toponymic suffix $-i c a^{57}$.

Septimanca (V). The name is recorded only by IA (435.2). Although Jungfer derived it from the Roman name Septimius ${ }^{58}$, it may come from IE *septm 'seven' (cf. Septemiacum in Lower Pannonia, $D A G$, p. 1229), or from an indigenous name *seppo-mantica (Land., p. 350).

Tela: see Gela

Termes (A). The name appears in Appian (Iber., pp. 76-77, 99) as Termentia (variant Termantia) and Termesos. Its inhabitants are called Termessioi by Diodorus Siculus (XXXIII 16) and Termestini by Livy (Epit. 54) and Tacitus (ann. 4.450). Despite the various endings, the name (at least under the Early Empire) must have been Termes, as shown by Pliny (III 27), Florus (III 22.9) and Ptolemy (II 6.55). Villar has recently argued that the root is the IE hydronym *ter- with suffix $-m a$ or $-m i s^{59}$; cf. GN Termidum in Gaul (AcS II, p. 1797).

Thermida (Ca). This toponym, attested only in Ptolemy (II 6.56) seems to be neither Celtic nor Iberian, but a Hellenized form of a name in term-. To$\operatorname{var}$ (Land., p. 236) may be right in seeing it as a duplicate of Termes (Arevaci).

Titulcia (Ca). The name appears in Ptolemy (II 6.56) and the itineraries (IA 436.1; Rav. 312.9). The etymology is unclear, but the gentilic name $a$. -

Spain», Romanica. Festschrift für Gerhard Rohlfs, ed. H. Lausberg and H. Weinrich, Halle, 1958, p. 99.

57 Curchin, «Five Celtic Town-names», p. 47.

58 J. Jungfer, «Noms de lieux hispaniques d'origine romaine», Bulletin Hispanique 6, 1904, p. 271. On the -anco- ending, cf. Schmoll, Sprachen der vorkeltischen Indogermanen Hispaniens, p. 59.

59 F. Villar, «Termes, Tarraco, Turiasu: Los dobletes con $r, r r$ en la toponimia prerromana hispana», Beiträge zur Namenforschung 28, 1993, pp. 329-330.

EMERITA. Revista de Lingüística y Filología Clásica (EM) - LXV 2, 1997, pp. 257-279 
tu.l.i.cu.m on a pre-Roman tessera from Cuenca province ${ }^{60}$ suggests at least the possibility of a parallel form *titulic- which could have been contracted into titulc-. This might come from the Celtiberian stem *tit-, seen in the ethnic name Titti (AcS II, p. 1858) and the coin legend ti.ti.a.co.s which implies a town $*$ Titia.

Toletum (Ca). The name appears in Livy (XXXV 7), Pliny (III 25), Ptolemy (II 6.56), IA (438.7; 446.4 and 7) and Rav. (312.10). Scholars have argued for the past century whether the name is Iberian, Ligurian or Celtic. Possible Celtic parallels for *tol- include Tolosa in Gaul, Tolbiacum in Lower Germany, and the Tolenses in Pannonia (cf. Land., p. 229); this does not really account for tolet-, though an -et- infix is found in British ethnic names such as Carvetii and Caletes (PRB 301). The existence of another Toletum in Galicia is suggested by an inscription mentioning Toletenses $($ HAEp $1965=$ AE 1961, p. 96).

Tucris (A). This occurs for certain only in Ptolemy (II 6.55). Tovar (Land., p. 366) suggests it might correspond to the ti.ce.r.s.e.bo.s of the Luzaga tablet, though Gil thinks this may rather be the Celtiberian equivalent of Latin posteris ${ }^{61}$. Possible IE roots for Tucris include *teu- 'to swell' and *tewa-, *tu- 'power(ful)' (PRB 480). No Celtic analogues in Tuc- are known; but if Tovar rightly equates it with Tic-, one might compare the river Ticinus in Narbonensis (DAG, p. 186).

Turiaso (Ce). Attested forms include tu.r.i.a.s.u (pre-Roman coins), Turiasso (Pliny III 24; Ptol. II 6.57; CIL XIII 586; IA 442.4, cf. 443.3) and Turriason (Rav. 311.1); but Hispano-Latin coins and a milestone (Eph. Epig. VIII, 295) give Turiaso. The name might come from an IE hydronymic root *ter-, cf. above on Termes ${ }^{62}$. Possible comparanda, not necessarily from the same root, include the DN Turiacus in Lusitania (CIL II 5551), numerous Tur- or Turi- PNs in Spain ${ }^{63}$, the Turones of Lugdunensis, the Gaulish GNs Turicum (modern Zürich) and Turedonnum (DAG, pp. 186, 611, 1234), and

60 Untermann, «Comentarios sobre inscripciones celtibéricas `menores'», pp. 357-358.

61 J. Gil, «Notas a los bronces de Botorrita y Luzaga», Habis 8, 1977, p. 172. The meaning and even the form of the word are uncertain: Villar, Estudios de celtibérico, 34-35.

62 Villar, «Termes, Tarraco, Turiasu», pp. 319-321.

63 Untermann, Atlas antroponímico, pp. 177-178. The Celticity of the name Turos is suggested by its appearance in both the Botorrita and Peñalba de Villastar inscriptions.

EMERITA. Revista de Lingüística y Filología Clásica (EM) - LXV 2, 1997, pp. 257-279 
the Old Irish hero Turenn.

Urbiaca (Ce). Livy calls the town Urbicua (XL 16.7), which sounds Iberian (cf. Ategua in Baetica), but says the town is in Celtiberia. IA (447.5) gives the form Urbiaca, which contains the authentic Celtiberian ending aca (see above on Arriaca). The itinerary locates it about four-sevenths of the distance from Lezuza to Zaragoza, which should place it near the boundary between Guadalajara and Teruel provinces, on the eastern edge of the territory of the Celtiberi. Although the meaning of the name is unclear, the river Urbia in Lugdunensis ( $D A G$, p. 613) seems to contain the same root. Schulten compares the river Urbicus (modern Orbigo) in Galicia, also Mount Urbion in the Iberian Cordillera ${ }^{64}$.

Urcesa (Ce). Ptolemy (II 6.57) alone mentions the name Urcesa, with variant Urcaisa. Schulten takes it as Iberian, comparing the Bastetanian GNs Urci and Mentesa ${ }^{65}$. However, the existence of a Celtiberian root urc-is suggested by the gentilic names Urcicon and Urcaloco(n) among the Arevaci (CIL II 2818, 2800), and the -esa, -aisa ending recalls the forms Caisesa, Secaisa found on Celtiberian coins of Caesada and Segeda (qq.v.).

Uxama Argaelorum (A). The name Uxama (variants Uxsama, Auxuma) is mentioned by numerous literary and epigraphic sources (see $A c S$ III, pp. 5960). It consists of Celtic *ukhs- (from IE *ups- 'high') plus the superlative ending -sama (see above, Segisama), and thus means 'very high (place)'. Numerous Ux- toponyms are known in Gaul and Britain, as well as Uxama Barca among the Autrigones. The Argaeli (cf. AE 1928, p. 175) may derive their name from IE *arg- 'white, shining', cf. Old Irish arget 'silver'.

Valebonga (Ce). The name is known only from IA (447.4). It probably comes from Celtic *val- 'to be strong' (GPN, p. 269), cf. Latin ualere. A similar toponym, Vallebana, is recorded in Aquitania (DAG, p. 403). -bonga, bana are perhaps variants of Gaulish *-bona, seen in GNs Iuliobona, Vindobona (DAG, pp. 604, 1236). If so, this etymology may support Saavedra's identification of Valebonga with modern Valbona ${ }^{66}$.

64 A. Schulten, Iberische Landeskunde, I, Strasbourg-Kehl, 1955, p. 351.

65 A. Schulten, «Urcesa», RE IX A, 1, 1961, col. 999.

66 E. Saavedra, Discursos leídos ante la Real Academia de la Historia, 2nd ed., Madrid, 1914, p. 108.

EMERITA. Revista de Lingüística y Filología Clásica (EM) - LXV 2, 1997, pp. 257-279 
Valeria (Ce). For the spelling, see Pliny (III 25), Ptolemy (II 6.57) and inscriptions (CIL II 3123-24). The name is Latin, from the nomen Valerius, whence scholars usually attribute its foundation to C. Valerius Flaccus, governor of Hispania Citerior from $93 \mathrm{BC}$. The original name of the pre-Roman settlement nearby (Los Galindos) is unknown.

Veluca (A). This is the spelling in Ptolemy (II 6.55); the later IA (442.1) gives Voluce, presumably in the locative case. On the transition from vel- to vol-, cf. Latin uolo $<*$ uelo. The otherwise inexplicable $u$ perhaps replaces an earlier medial $i$, cf. Vulgar Latin maxumus etc. Evans (GPN, pp. 276-77) cites numerous names in $\mathrm{Vel}(\mathrm{l})$-, from a variety of roots, not all suitable for toponyms. The most convincing etymology for our name would be Celtic *vel- 'grass, wood' (GPN, p. 275) plus the toponymic suffix -ica (see above, Albonica), yielding 'grassy (or woody) place'.

Varada (Ca). The name, recorded only by Ptolemy (II 6.56), recalls numerous Var- names in Gaul and Britain. These are believed to derive from a pre-Celtic hydronymic root *vara-, possibly cognate with Sanskrit var 'water' (see lengthy discussion in PRB 486). On the -ada ending, cf. above, Arecorada.

Vicus Cuminarius (Ca). Only IA furnishes this name (445.6), which clearly derives from Latin cuminum 'cumin'. Cumin was grown in Carpetania (Pliny XIX 161) and was used as a spice by both the Celts and Romans (Athenaeus IV 152; Pliny XX 159). On uicus names in Spain, cf. my earlier study ${ }^{67}$.

Viminacium (V). This name is attested by Ptolemy (II 6.49), the itineraries (IA 449.2; 453.9; Biminatium in Rav. 318.16) and inscriptions (CIL II $2671,6115)$. It is homonymous with the capital of Moesia Superior. The name is more likely derived from a Celtic adjective *viminac- (cf. the Gaulish river Vimina: AcS III, p. 320) than from Latin Viminius, but its meaning is unknown.

Visontium (P). Our sole source is Ptolemy (II 6.53). The name is paralleled by Vesontio in Gaul and Visontium in Pannonia Superior. Earlier scholars suggested that the name might be Ligurian or Illyrian ${ }^{68}$; at any rate, it seems

${ }^{67}$ Curchin, «Vici and pagi», pp. 328-338.

68 Arbois de Jubainville, «Les Celtes en Espagne», p. 23. Cf. AcS III, 404; Pokorny, «UrEMERITA. Revista de Lingüística y Filología Clásica (EM) - LXV 2, 1997, pp. 257-279 
non-Celtic.

\section{Name Origins (Certain or Probable)}

Arevaci:

Pre- or Para-Celtic: Clunia, Palantia, Termes, Tucris(?) $=4(36 \%)$

Celtic: Segontia, Segovia, Uxama, Veluca $=4(36 \%)$

Latin or Romanized: Colenda(?), Confluenta, Nova Augusta $=3$ (27\%)

\section{Carpetani:}

Pre- or Para-Celtic: Alces(?), Barnacis, Caraca(?), Complutum(?), Ilarcuris, Ilurbida, Ispinum, Laminium, Rigusa(?), Thermida(?), Varada $=11$ (48\%)

Celtic: Contrebia Carbica, Libora(?), Mantua, Metercosa(?), Miacum(?), Titul$\operatorname{cia}(?), \operatorname{Toletum}(?)=7(30 \%)$

Latin or Romanized: Alternia, Arriaca, Murum, Paterniana, Vicus Cuminarius $=5$ $(22 \%)$

\section{Celtiberi:}

Pre- or Para-Celtic: Bilbilis, Bursao, Histonium, Laxta, Libana(?), Turiaso, Urbia$c a(?)=7(25 \%)$

Celtic: Alaba, Albonica(?), Arcobriga, Attacum, Belgeda, Belsinum(?), Caesada, Centobriga, Certima, Consabura(?), Ercavica(?), Lutia(?), Mediolum, Nertobriga, Ocilis, Segeda, Segobriga, Urcesa(?), Valebonga $=19$ (68\%)

Latin or Romanized: Aquae Bilbilitanorum, Valeria $=2$ (7\%)

\section{Pelendones:}

Pre- or Para-Celtic: Numantia(?), Savia(?), Visontium $=3(50 \%)$

Celtic: Arecorada, Contrebia Leucada $=2(33 \%)$

Latin or Romanized: Augustobriga $=1(17 \%)$

\section{Turmogi:}

Pre- or Para-Celtic: Pisoraca $(?)=1(17 \%)$

geschichte», p. 154.

EMERITA. Revista de Lingüística y Filología Clásica (EM) - LXV 2, 1997, pp. 257-279 
Celtic: Ambisna, Brauum, Deobrigula, Dessobriga, Segisamo = $5(83 \%)$

Latin or Romanized: $0(0 \%)$

Vaccaei:

Pre- or Para-Celtic: Albocela(?), Amallobriga(?), Autraca(?), Avia(?), Cougion(?),

Lacobriga(?), Palantia, Pintia, Rauda, Sabaris, Saldania, Septimanca $=12$ $(48 \%)$

Celtic: Acontia, Camala, Cauca(?), Gela(?), Intercatia, Meoriga(?), Nivaria(?), Ocelodurum, Segontia Paramica, Sentica, Viminacium = $11(44 \%)$

Latin or Romanized: Porta Augusta, Segisama Iulia = 2 (8\%)

\section{Conclusions}

It will be clear from these lists that many toponyms cannot be securely classified as Celtic or non-Celtic. In some cases the name has no decisive parallels in any language; in others, the name appears to combine Celtic and non-Celtic elements. The fact that a name-element may be paralleled in a Celtic region such as Gaul does not guarantee that it is Celtic, for Gaul too embraced a multitude of ancient peoples. Thus the figures presented above for Celtic, pre-Celtic and para-Celtic toponyms must be taken as approximations only.

Nonetheless, even these approximate figures yield some interesting conclusions about pre-Roman toponymy. Among the Arevaci, Pelendones and Vaccaei, the proportions of Celtic and pre- or para- Celtic names are roughly equal. The Carpetani (the southernmost of the chiefdoms) show a high proportion of non-Celtic, largely Iberian toponyms. The Celtiberi, on the other hand - and contrary to the outmoded view that they were a racial mixture of Celts and Iberians - have a relatively low proportion of Iberian (and other non-Celtic) names. The Turmogi, despite having very few towns, show a very high proportion of Celtic to non-Celtic place-names; indeed, the only arguably non-Celtic toponym in this zone appears to have a Celtic ending.

Though it is often difficult to distinguish between Celtic, pre-Celtic and para-Celtic names, there can be little doubt as to which names are Romanized. From the figures above, we see that the Arevaci and Carpetani are high 
in Romanized names, which represent $27 \%$ and $22 \%$ respectively of the toponyms in those chiefdoms. These data accord with recent quantitative studies of the epigraphy of Central Spain, which show that the Arevaci and Carpetani have a high rate of Roman (as compared with indigenous) deities, a high rate of tria nomina in personal nomenclature, and a low rate of illiteracy (as indicated by spelling irregularities and age-rounding). ${ }^{69}$ Similarly it is predictable that the Turmogi and Vaccaei, who have a very low rate of Roman deities and tria nomina, and a relatively high rate of illiteracy, are at the bottom of the scale, with $0 \%$ and $8 \%$ of their toponyms Romanized. The Pelendones, who fall between these high and low groups in terms of deities and tria nomina (though having the highest illiteracy rate in the region) likewise fall between the Arevaci/Carpetani and Turmogi/Vaccaei, with 17\% Romanized toponyms. The real surprise in this study is the Celtiberi, who rank just below the Arevaci/Carpetani in terms of Roman deities and tria nomina, and have the lowest rate of spelling abnormalities, but can only claim $7 \%$ of their toponyms as Romanized.

One coincidence may be significant: the Celtiberi and Turmogi, the only chiefdoms where Celtic toponyms hold a decisive lead over pre- or para-Celtic ones, are also the two chiefdoms with the lowest incidence (less than $10 \%$ ) of Romanized place-names. This seems to suggest that strongly Celtic areas may have been more resistant to Romanization of toponymy than those whose pre-Roman nomenclature was more heterogeneous; conversely, in chiefdoms where toponymy was already multilingual before the Romans arrived, there may have been fewer obstacles to the introduction of new geographic names. The validity of this hypothesis must await testing in other Celtic regions.

LEONARD A. CURCHIN

69 L.A. Curchin, «From limes to Latinitas. Roman Impact on the Spanish Meseta», Studien zu den Militärgrenzen Roms, III, Stuttgart, 1986, pp. 692-695; idem, «Literacy in the Roman Provinces. Qualitative and Quantitative Data from Central Spain», American Journal of Philology 116, 1995, pp. 461-476.

EMERITA. Revista de Lingüística y Filología Clásica (EM) - LXV 2, 1997, pp. 257-279 